\title{
The Effect of Good Corporate Governance (GCG) Mechanism on Earnings Management Practices of The Stubben Model (Study Case on Mining Sector Companies Listed on The Indonesia Stock Exchange 2014-2019)
}

\author{
Muhammad Fairus, Pardomuan Sihombing
}

\begin{abstract}
This study was prepared with the intention of analyzing the impact of the Good Corporate Governance (GCG) Mechanism on the Stubben Model of Profit Management (analysis of Mining Sector Companies on the Indonesia Stock Exchange for the period 2014-2019). The population used in the study is the mining sector companies on the IDX. The sample selection method used purposive sampling technique. To process data after sample selection, compile a research model, determine the variables analyzed in the study, and propose a hypothesis, the next step is to carry out data processing procedures through regression analysis with panel data. The results of the analysis conclude that (1) Institutional Ownership has a negative and significant impact on Earnings Management, (2) Managerial Ownership has a negative and significant impact on Earnings Management, (3) The Independent Board of Commissioners has a negative and significant impact on Earnings Management, (4) The Audit Committee has a negative and significant impact on Earnings Management, and (5) Audit Quality has a negative and significant impact on Earnings Management.
\end{abstract}

Index Terms - Institutional Ownership, Managerial Ownership, Independent Commissioner, Audit Committee, Audit Quality.

\section{INTRODUCTION}

The data contained in financial published reports is basically a summary of the company's achievements in a certain period. Considering the importance of earnings information as a basis for consideration for someone to make investment decisions, company managers do their best so that the profits included in the published annual reports give a positive signal to potential investors to make investments.

Jogiyanto [1] states that the role of earnings is important in various decision-making processes, so that there is a tendency for managers to influence company reported earnings with certain motives known as earnings management. Earnings management is the manager's opportunistic behavior to deceive investors and maximize their welfare because they control more information than for personal and / or corporate interests [2].

Published on November 18, 2020.

Muhammad Fairus, Master of Management, Mercu Buana University, Indonesia.

(corresponding e-mail: fairussmuhammad ${ }^{@}$ gmail.com)

Pardomuan Sihombing, Master of Management, Mercu Buana University, Indonesia.

(corresponding e-mail: pardomuan.sihombing ${ }^{@}$ mercubuana.ac.id)
The phenomenon of earnings management is also experienced by companies belonging to the mining sector on the Indonesia Stock Exchange. The nature and characteristics of the mining industry are different from other industries. The mining industry is a high profile industry that has visibility from stakeholders, requires a very large investment cost, long term, high competition, full of risk and high uncertainty, making the problem of funding a major issue related to company development. Here are some cases of earnings management in the mining sector:

a. In 2015, the mode of fraud allegedly committed by PT

Medco E\&P Indonesia was by manipulating financial report data through cost recovery calculations which could reduce the amount of revenue sharing funds distributed by the government (Skornews.com, accessed on December 20th, 2017).

b. In 2016, PT Timah (Persero) Tbk allegedly provided a fictitious financial report in the first semester of 2015. This fictitious financial reporting activity was carried out to cover PT Timah's continued worrying financial performance (Tambang.co.id, accessed on December 20th, 2017).

c. In 2017 , the Directors of CKRA deliberately inflated the asset value of CKRA by falsely consolidating financial statements and exaggerating the value of the paid-up capital of the mining company (Beritalima.com, accessed on December th 2017).

Apart from the phenomenon of earnings management, the mining sector is one of the sectors on the Indonesian Stock Exchange which is very volatile. This is because the mining sector is known to have characteristics that depend on natural resource commodities in Indonesia.

There are differences in research results (gap research) regarding the impact of the GCG component on earnings management practices. Octavia [3] and Kazemian and Zuraidah [4] found that Institutional Ownership has a negative and significant effect on Earnings Management. This is not in line with the findings made by Salehi et al [5] and Kamran and Attaullah [6] who found that Institutional Ownership does not have a significant impact on earnings management.

Research conducted by Reyna [7] found that Managerial Ownership has a negative and significant impact on Earnings Management. This finding is not in line with Spinos' research [8] that managerial ownership does not have a significant impact on earnings management. 


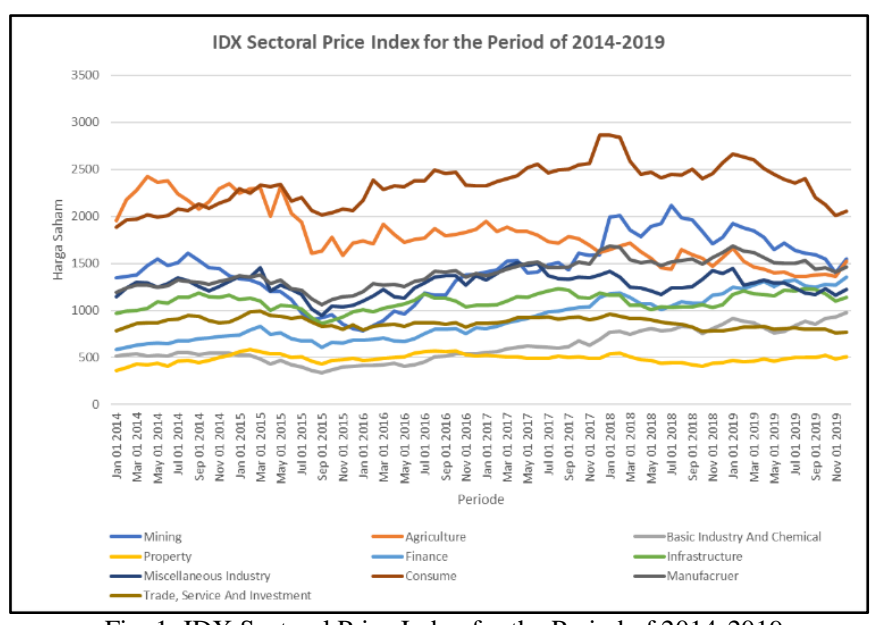

Fig. 1. IDX Sectoral Price Index for the Period of 2014-2019.

Research conducted by Man and Brossa [9] and Ramachandran, et al [10] states that the Independent Board of Commissioners has a negative impact on earnings management. This is not in accordance with research by Daghsni et al [11] that the Independent Commissioner has no significant effect on earnings management.

Research conducted by Sochib [12] states that the Audit Committee has a negative and significant impact on earnings management. This is not in line with the research conducted by Narolita and Komang [13] that the audit committee is not able to prevent and reduce earnings management practices.

\section{LITERATURE REVIEW}

Scott [14] explains that earnings management is management intervention in the policy of financial reporting data for parties outside the company so that it can manipulate earnings reporting where management can use the leeway in the use of accounting methods, make policies (discretionary) that can hasten or delay expenses and income, company profit as expected. According to Martani et al [15] earnings management is described as planning the timing of revenues, expenses, gains and losses to smooth out fluctuations in earnings.

Stubben [16] conducted a study on the advantages of accrual models and revenue models to find simulated earnings management and actual earnings management. Stubben [16] took a sample of earnings management data in companies (except for the financial and insurance sectors). Then do the manipulation of the income and expenses. The accrual model and the revenue model were tested to detect this manipulation. The results show that the revenue model is stronger in detecting such revenue and expense manipulations [16].

Institutional ownership is a situation where the institution has shares in a company [17]. This is because institutional investors have more resources than other shareholders, so they are considered capable of implementing good supervisory mechanisms. From the above understanding, it can be concluded that institutional ownership is a condition in which external institutions or institutions also own shares in the company.
According to Sukirni [18] managerial ownership is the portion of owners in the company and managers actively participate in decision making in the company concerned. From the above definition, it can be concluded that managerial ownership is the owner of the company's shares from management who participates in the decision making of a company concerned.

According to the National Committee on Governance [19], an independent board of commissioners is a board of commissioners that is not directly connected to management, other members of the board of commissioners and controlling shareholders, and is free from conflicts of interest that can affect its ability to act independently for the benefit of the company. Based on the above definition, the writer concludes that the independent board of commissioners is a member of the commissioner who is in the company (has no affiliation with the company).

Hamdani [17] argues that the audit committee is formed by the Board of Commissioners of a listed company, whose members are selected and terminated by the board of commissioners of a listed company to assist the company's board of commissioners in carrying out necessary checks on the function of the board of directors to manage the company. The duties of the audit committee include tracking company accounting policies, evaluating internal controls, analyzing external reporting systems and compliance with regulations [20].

Amijaya and Prastiwi [21] state that qualified auditors are able to detect earnings management actions by clients so that managers will limit the amount of discretionary accruals. Based on the above statement, it can be concluded that audit quality is the ability to enhance the quality of the company's financial reporting.

Based on literature review, this study compiles a framework for testing hypotheses and answering the problem formulations in this study.

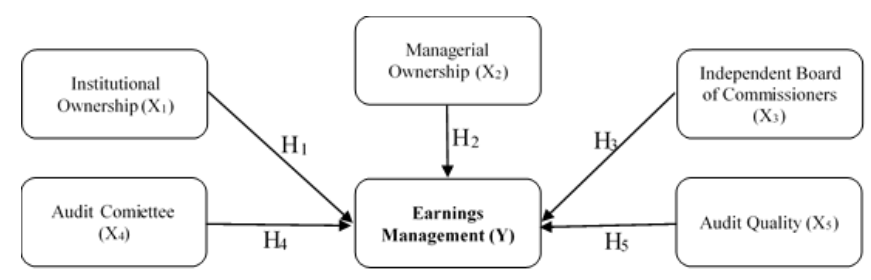

Fig. 2. Research Framework.

\section{Research Methodology}

This type of research used in this research is the type of causal research. This type of causal research is used to prove the relationship between cause and effect of several variables. The operational definition of this research can be seen in Table 1 below: 
TABLE 1: OPERATIONAL DEFINITION AND VARIABLE MEASUREMENT

\begin{tabular}{|c|c|c|c|}
\hline No & Variable & $\begin{array}{c}\text { Definition } \\
\end{array}$ & $\begin{array}{lc}\text { Measurement } \\
\end{array}$ \\
\hline 1 & $\begin{array}{c}\text { Earnings } \\
\text { Management (Y) }\end{array}$ & $\begin{array}{l}\text { Management intervention in } \\
\text { preparing financial reports for parties } \\
\text { outside the company so as to } \\
\text { manipulate earnings reporting as } \\
\text { expected. }\end{array}$ & 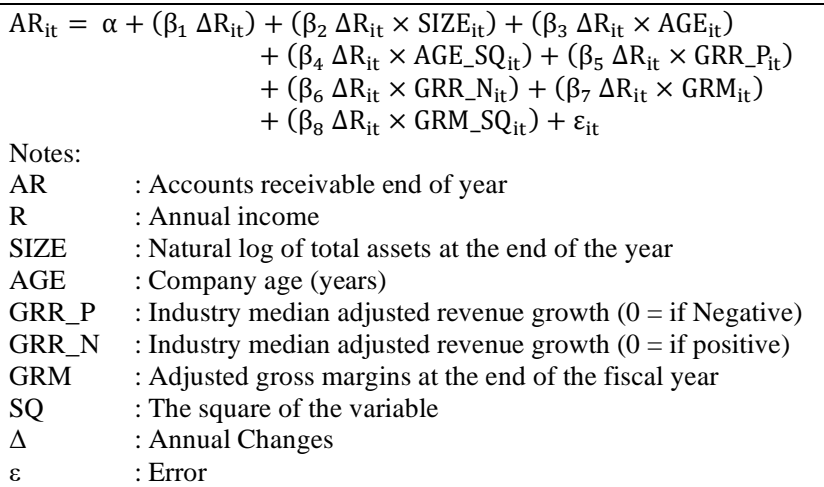 \\
\hline 2 & $\begin{array}{c}\text { Institutional } \\
\text { Ownership }\left(\mathrm{X}_{1}\right)\end{array}$ & External ownership of shares & $\mathrm{KI}=\frac{\text { Number of Institutional Shares }}{\text { Total Company Shares }} \times 100 \%$ \\
\hline 3 & $\begin{array}{c}\text { Managerial } \\
\text { Ownership }\left(\mathrm{X}_{2}\right)\end{array}$ & $\begin{array}{l}\text { The level of management's share } \\
\text { ownership so that it can participate in } \\
\text { making decisions }\end{array}$ & $\mathrm{KM}=\frac{\text { Total Manager Shares }}{\text { Total Company Shares }} \times 100 \%$ \\
\hline 4 & $\begin{array}{c}\text { Independent } \\
\text { Board of } \\
\text { Commissioners } \\
\left(\mathrm{X}_{3}\right)\end{array}$ & $\begin{array}{l}\text { The board of commissioners does not } \\
\text { come from management, other } \\
\text { members of the board of } \\
\text { commissioners and the controlling } \\
\text { shareholder } \\
\text { A committee formed by the Board of }\end{array}$ & DKI $=\frac{\text { Number of Independent Commissioners }}{\text { Total Number of Commissioners }} \times 100 \%$ \\
\hline 5 & $\begin{array}{l}\text { Audit Committee } \\
\qquad\left(\mathrm{X}_{4}\right)\end{array}$ & $\begin{array}{lll}\text { Commissioners to carry out } \\
\text { supervisory } \\
\text { responsibilities }\end{array}$ & $\mathrm{KA}=\frac{\text { Total Audit Committee }}{\text { Total Board of Commissioners }} \times 100 \%$ \\
\hline 6 & $\begin{array}{l}\text { Audit Quality } \\
\qquad\left(\mathrm{X}_{5}\right)\end{array}$ & $\begin{array}{l}\text { Auditor foresight in the detection and } \\
\text { reporting of fraud in client financial } \\
\text { reports }\end{array}$ & $\begin{array}{l}\text { Measurement of variables using dummy variables, the value of } 1 \text { if the } \\
\text { company is audited by KAP the big- } 4 \text {, and } 0 \text { if the other (Non The big- } 4 \text { ) }\end{array}$ \\
\hline
\end{tabular}

\section{RESUlt AND Discussion}

In the first stage before regression analysis is carried out, here are the descriptive statistics of the research variables.

\section{A. Descriptive Statistical Analysis Results}

Descriptive statistics are a general description of the data which is the research variable. Descriptive statistical analysis will produce information consisting of the average value (mean), middle value (median), maximum value and minimum value from the research data. Following are the results of the descriptive statistical analysis of the study.

In the Table 2, it is known that the number of observed data is 84 and there are no missing data (all data were successfully processed). In the measurement of earnings management, there is an average value of -5.56 . This shows that mining sector companies listed on the IDX carry out profit management with an Income Minimization strategy. This is because the average value of earnings management shows a negative number.

In the Institutional Ownership variable, the mean is $47.71 \%$. This shows that mining sector companies have a fairly good portion of institutional ownership so that earnings management can be minimized. In the Managerial Ownership variable, the mean is $7.19 \%$. This shows that companies in the mining sector have a low portion of managerial ownership so that managers have less supervision of the running of the company.

On the Independent Commissioner Board variable, the mean is $36.43 \%$. This shows that mining sector companies listed on the Indonesia Stock Exchange have significant independent parties to the company. On the audit committee variable, the mean was $71.87 \%$. This shows that mining sector companies have a large proportion of audit committees. This makes it easier for companies to produce better financial reports.

In the audit quality variable, it is known that the companies that were not audited by Big 4 KAP were PT Radiant Utama Interinsco Tbk., PT Central Omega Resources Tbk, PT Mitra Investindo Tbk, PT SMR Utama Tbk, PT Energi Mega Persada Tbk, and PT Delta Dunia Makmur. Tbk. Meanwhile, other companies have been audited by KAP Big 4, which shows that the quality of the resulting financial reports is better.

TABLE 2: DESCRIPTIVE STATISTICAL ANALYSIS RESUlTS

\begin{tabular}{ccccccc}
\hline & $\begin{array}{c}\text { Earnings } \\
\text { Management }\end{array}$ & $\begin{array}{c}\text { Institutional } \\
\text { Ownership }\end{array}$ & $\begin{array}{c}\text { Managerial } \\
\text { Ownership }\end{array}$ & $\begin{array}{c}\text { Independent Board } \\
\text { of Commissioners }\end{array}$ & $\begin{array}{c}\text { Audit } \\
\text { Committee }\end{array}$ & Audit Quality \\
\hline Mean & -5.56536 & 47.71845 & 7.19929 & 36.43167 & 71.87167 & 0.57143 \\
Median & -5.41000 & 45.34000 & 0.05500 & 33.33000 & 66.67000 & 1.00000 \\
Maximum & -3.73000 & 99.99000 & 57.55000 & 57.14000 & 150.00000 & 1.00000 \\
Minimum & -16.36000 & 4.92000 & 0.01000 & 20.00000 & 33.33000 & 0.00000 \\
Observations & 84 & 84 & 84 & 84 & 84 & 84 \\
\hline
\end{tabular}




\section{B. Results of Regression Model Testing}

In this study, panel data regression analysis was used. Through testing panel data regression data analysis, researchers will find out the influence between the variables tested to answer the problem formulation and research hypotheses. Following are the results of the panel data regression analysis in the study.

TABLE 3: PANEL DATA REGRESSION ANALYSIS RESULTS

\begin{tabular}{lccc}
\hline \multirow{2}{*}{ Chow Test } & Cross-section F & \multicolumn{2}{c}{ Result } \\
\cline { 2 - 4 } \multicolumn{1}{c}{ Haussman Test } & 0.000 & \multicolumn{2}{c}{ PLS is not the best model } \\
\cline { 2 - 4 } & \multicolumn{1}{c}{ Variable } & Prob. & \multicolumn{2}{c}{ Result } \\
\hline \multicolumn{2}{c}{ Cofed Effect } \\
\hline C & -4.806188 & -3.896028 & 0.0000 \\
INSTITUTIONAL OWNERSHIP & -0.218467 & -2.635031 & 0.0008 \\
MANAGERIAL OWNERSHIP & -0.432120 & -5.537997 & 0.0000 \\
INDEPENDENT BOARD OF COMMISSIONERS & -0.350027 & -2.913289 & 0.0009 \\
AUDIT COMMITTEE & -0.317992 & 2.398531 & 0.0260 \\
AUDIT QUALITY & -0.306022 & 2.325919 & 0.0032 \\
F Test & F-Statistic & Prob & Result \\
& 21.053 & 0.000 & Significant \\
\hline \multicolumn{1}{c}{ Coefficient of Determination (R-Squared) } & & \multicolumn{2}{c}{0,672} \\
\hline
\end{tabular}

Source: Output Eviews 10 (Processed Data)

a. Constant value of $-4,806$ with a significance value of 0,000 . Due to the significance $<0.05$, the value is constant, and it can be interpreted that if all independent variables are considered constant or do not change, the amount of Earnings Management is 4.806 .

b. The regression coefficient value for Institutional Ownership (KI) is -0.218 with a significance value of 0.008 . Based on this, $\mathrm{H} 0$ is rejected and $\mathrm{Ha}$ is accepted. This shows that there is a negative and significant influence of Institutional Ownership on Earnings Management. The regression coefficient figure shows that if the Institutional Ownership (KI) increases by one unit, Profit Management will decrease by 0.218 only if the other variables are constant (constant).

c. The regression coefficient value for Managerial Ownership (KM) is -0.432 with a significance value of 0.000. Based on this, $\mathrm{H} 0$ is rejected and $\mathrm{Ha}$ is accepted. This shows that there is a negative and significant influence of Managerial Ownership on Earnings Management. The regression coefficient number shows that if Managerial Ownership (KM) increases by one unit, Earnings Management will decrease by 0.432 only if the other variables are constant (constant).

d. The regression coefficient value for the Independent Commissioner (DKI) is -0.350 with a significance value of 0.000 . Based on this, $\mathrm{H} 0$ is rejected and $\mathrm{Ha}$ is accepted. This shows that there is a negative and significant influence of the Independent Commissioner variable on earnings management. The regression coefficient number shows that if Managerial Ownership (KM) increases by one unit, Earnings Management will decrease by 0.350 only if the other variables are constant (constant).

e. The regression coefficient value of the Audit Committee (KA) is -0.317 with a significance value of 0.026. Based on this, $\mathrm{H} 0$ is rejected and $\mathrm{Ha}$ is accepted. This shows that there is a negative and significant effect of the Audit Committee variable on earnings management. The regression coefficient number shows that if the Audit Committee (KA) increases by one unit, the Profit Management will decrease by 0.317 only if the other variables are constant (constant).

f. The regression coefficient value of Audit Quality (KAD) is -0.306 with a significance value of 0.003 . Based on this, H0 is rejected and $\mathrm{Ha}$ is accepted. This shows that there is a negative and significant effect of the Audit Quality variable on Earning Management. The regression coefficient number shows that if the Audit Quality increases by one unit, the Earnings Management will decrease by 0.306 only if the other variables are constant (constant).

g. In the F test it is known that the F-Statistic value of 21,053 is significant at alpha 0,000. Based on this, H0 is rejected and $\mathrm{Ha}$ is accepted. This shows that simultaneously (together) Institutional Ownership (KI), Managerial Ownership (KM), the Independent Board of Commissioners (DKI), the Audit Committee (KA), and Audit Quality (KAD) have a significant effect on Earning Management (MA) ).

h. The coefficient of determination (R-Squared) is 0.672 . This shows that the percentage of the contribution of the influence of the independent variable on the dependent variable is $67.2 \%$. In other words, it can be interpreted that the independent variables (Institutional Ownership (KI), Managerial Ownership (KM), Independent Board of Commissioners (DKI), Audit Committee (KA), and Audit Quality (KAD)) used in this study are able to explain the variables. the dependence of Earnings Management is $67.2 \%$. While the remaining $32.8 \%$ is influenced by other variables.

\section{Discussion of Research Results}

Based on the research results, it is known that Institutional Ownership is able to significantly reduce Earning Management practices. Institutional ownership has the ability to control management through an effective monitoring process so that it can reduce earnings management [22]. The results of this study are in line with previous research conducted by Kazemian and Zuraidah [4] which states that Institutional Ownership has a negative and significant effect on Earning Management.

Based on the research results, it is known that Managerial Ownership is able to significantly reduce Earning Management practices. Earnings management practices are 
largely determined by the motivation of company managers. Different motivations will produce different amounts of earnings management [22]. Asward and Lina [23] conclude that managerial ownership has succeeded in reducing agency problems from managers and aligning the interests of managers with shareholders. Previous research conducted by Hazri and Sugiyarti [24] stated that Managerial Ownership can significantly reduce Earning Management practices.

The results showed that the Independent Board of Commissioners was able to significantly reduce Earning Management practices. The independent board of commissioners functions and is responsible for ensuring that the company establishes the right strategy (monitoring schedules, budgets and strategy effectiveness), does not violate applicable regulations, and ensures that the principles and practices of good corporate governance are well obeyed and implemented [25].

The results showed that the Audit Committee was able to significantly reduce Earning Management practices. According to Boediono [26] the audit committee is responsible for overseeing financial reports, overseeing external audits, and observing internal control systems (including internal audits) can reduce the opportunistic nature of management that performs earnings management by supervising financial reports and supervising the external audit. Previous research by Latif and Fahad [27] explained that the Audit Committee was able to significantly reduce Earning Management practices.

The results showed that Audit Quality was able to significantly reduce Earning Management practices. The auditor quality dimension is the size of the public accounting office or KAP which is considered the most important indicator [28]. The results of this study are in line with previous research conducted by Ulina et al [29] which states that Audit Quality can significantly reduce Earning Management practices.

\section{CONCLUSION}

The conclusions obtained in this study are (1) Institutional Ownership is able to significantly reduce Earning Management practices, (2) Managerial Ownership can significantly reduce Earning Management practices, (3) Independent Board of Commissioners is able to significantly reduce Earnings Management practices, (4) Committee Audit is able to reduce Earning Management practices significantly, and (5) Audit Quality can significantly reduce Earning Management practices

Based on the results of the research obtained, the following are suggestions put forward in this study (1) it is recommended that mining companies increase the portion of Institutional ownership as part of an oversight in managing the company, (2) it is recommended that mining companies increase the portion of managerial ownership because of the share ownership owned by the manager. is one way to reduce agency costs where managerial ownership can align the interests of managers with those of owners, (3) it is recommended that mining companies increase the number of Independent Commissioners because independent commissioners can minimize conflict of interest because they will be objective in decision making, where independent commissioners will provide input in case of business management irregularities so that adverse selection and moral hazard can be avoided, (4) it is recommended companies increase the number of Independent Commissioners because of Independent Saris can minimize conflict of interest because it will be objective in decision making, where independent commissioners will provide input if there is business management irregularities so that adverse selection and moral hazard can be avoided, (5) The results of the study show that Audit Quality can reduce the practice of Earnings Management significant. Therefore, it is recommended companies use a credible KAP that has met the qualifications and permits of the BPK and OJK in order to guarantee quality and reliable reports (information). (6) It is recommended that in further research, use other variables that influence corporate earnings management such as financial variables, namely Profitability, Liquidity, Solvency and Market Ratio for BUMN and private companies.

\section{REFERENCES}

[1] Jogiyanto, Hartono. (2014). Teori Portofolio dan Analisis Investasi. Yogyakarta: BPFE

[2] Gonzalez, Ultero N., and Callado- Muñoz. (2016). "Do Investors React to Corpo- rate Governance News? An Empirical Analysis for the Spanish Market". BRQ Business Research Quarterly, 19(1).

[3] Octavia, Evi. (2017). "Implikasi Corporate Governance dan Ukuran Perusahaan pada Manajemen Laba". Jurnal Akuntansi Multiparadigma, 8(1).

[4] Kazemian, Soheil and Zuraidah Mohd Sanusi. 2015. "Earnings Management and Ownership Structure". Procedia Economics and Finance, 31(2).

[5] Salehi, et al (2017). "The Effect Of Corporate Governance And Audit Quality On Disclosure Quality: Evidence From Tehran Stock Exchange". Periodica Polytechnica Social And Manahement Sciences. 25(1).

[6] Kamran and Attaullah (2014). "The Impact Of Corporate Governance And Ownership Structure On Earnings Management Practice: Evidence From Listed Companies In Pakistan". The Lahore Journal Of Economics. 19(2).

[7] Reyna (2012). "Corporate Governance, Ownership Stucture and Performance in Mexico". International Business Research. 5(11).

[8] Spinos (2013). Managerial Ownership and Earnings management in times of financial Crisis: Evidence from the USA. MSc. Thesis submitted to the School of Economics, Erasmus University.

[9] Man and Brossa (2013). "Corporate Governance And Earnings Management: A Survey Of Literature". Journal of Applied Business Research. 29(2).

[10] Ramachandran, Jayalakshmy., Zipora Adoyo Ngete., Ramaiyer Subramanian., and Murali Sambasivan. (2014). "Does Corporate Governance Influence Earning Management? Evidence From Singapore". Proceedings of the Australian Academy of Business and Social Sciences Conference.

[11] Daghsni, O., Zouhayer, M. \& Mbarek, K.B.H. (2016). "Earnings Management and Board Characteristics: Evidence from French Listed Firms". Account and Financial Management Journal. 1(2).

[12] Sochib. (2015). "Pengaruh Penerapan Good Corporate Governance terhadap Manajemen Laba serta Kinerja Keuangan”. Jurnal Wiga, $5(1)$.

[13] Narolita, Ekasari dan Komang Ayu Krisnadewi. (2016). "Pengaruh Penerapan Corporate Governance pada Manajemen Laba oleh Chief Executive Officer Baru". E-Jurnal Akuntansi Universitas Udayana. Vol. 14 No. 1.

[14] Scott, William R. (2015). Financial Accounting Theory. Sixth Edition. Canada: Person Prentice Hall.

[15] Martani, Dwi. 2012. Akuntansi Keuangan Menengah Berbasis PSAK. Jakarta: Salemba Empat.

[16] Stubben, Stephen R. (2010). "Discretionary Revenues As A Measure Of Earnings Management". The Accounting Review, 85(2).

[17] Hamdani. (2016). Good Corporate Governance (Tinjauan Etika dalam Praktik Bisnis. Jakarta: Mitra Wacana Media. 
[18] Sukirni, Dwi. (2012). "Kepemilikan Manajerial, Kepemilikan Institusional, Kebijakan Dividen dan Kebijakan Hutang Analisis Terhadap Nilai Perusahaan". Accounting Analysis Journal. Vol. 1 No. 2.

[19] National Committee on Governance (2017). Pedoman Umum Good Corporate Governance Indonesia. Jakarta: Komite Nasional Kebijakan Governance.

[20] Sedarmayanti. (2012). Manajemen Sumber Daya Manusia. Jakarta: Refika Aditama Eresco.

[21] Amijaya, M. D., \& Prastiwi, A. (2013). "Pengaruh Kualitas Audit terhadap Manajemen Laba". Diponegoro Journal of Accounting. 1-13

[22] Hidayanti, Ery., Ratna Widjayanti., Dahniar Paramita. (2014). "Pengaruh Good Corporate Governance terhadap Praktik Manajemen Laba Riil pada Perusahaan Manufaktur". Jurnal Wiga, 4(2).

[23] Asward, I., dan Lina. (2015). "Pengaruh Mekanisme Corporate Governance terhada Manajemen Laba dengan Pendekatan Conditional Revenue Model”. Jurnal Manajemen Teknologi, 14(1).

[24] Hazri, Muhammad dan Sugiyarti FatmaLaela. (2013). "Pengaruh Mekanisme Good Corporate Governance terhadap Praktik Manajemen Laba: Studi pada Perusahaan yang Termasuk dalam CGPI". Tazkia Islamic Business and Finance Review. Vol. 4 No. 2

[25] Sulistyanto, H. (2014). Manajemen Laba: Teori dan Model Empiris. Jakarta: PT Grasindo.

[26] Boediono. (2013). Ekonomi Mikro. Yogyakarta: BPFE.

[27] Latif, Aysha S and Fahad Abdullah. (2015). "The Effectiveness of Corporate Governance in Constraining Earnings Management in Pakistan". The Lahore Journal of Economics. Vol. 20 No. 1.

[28] Rosena, et al (2016)"Pengaruh Kualitas Audit Dan Laverage Terhadap Manajemen Laba Dengan Ukuran Perusahaan Sebagai Variabel Pedemorasi”. Jurnal Magister Akuntansi Trisakti 3, 1(21).

[29] Ulina, et al (2018). "Pengaruh Kualitas Audit Dan Komite Audit Terhadap Manajemen Laba Pada Perusahaan Manufaktur Yang Tercatat Di Bursa Efek Indonesia”. Jurnal Tirtayasa Ekonomika, 13(1). 